Technical University of Cluj-Napoca, North University Centre of Baia Mare

Baia Mare, Romania

NICOLAE FELECAN

\title{
FEMININE NAMES IN CURRENT ROMANIAN HODONYMY*
}

Keywords: hodonyms, gender inequality, urban toponymy, commemorative names, Romania

\section{INTRODUCTION}

There are people who inspire in many fields of knowledge: they play the role of pioneers and represent role models for disciples. They set up institutions and schools and publish scientific papers. Thus, their professional path remains a landmark in the collective memory. Prof. Barbara Czopek-Kopciuch fits into this category and what she leaves behind is essential not only for the journal "Onomastica", where she served as editor-in-chief, or for various Polish and international professional organizations, but also for the entire international community. She published numerous notable works in the field of onomastics, and our collaboration dates back to 2013 when the study "Names of companies in Poland" was included in the volume "Onomastics in Contemporary Public Space" (2013, pp. 120-130). Also, her last article — "Multiculturalism in Polish Toponymy" — was printed posthumously in the volume "Names and Naming: Multicultural Aspects" (2021, pp. 331-343). ${ }^{1}$ Considering the collaboration between us corroborated with the Cracow-based researcher's interests, we have chosen to devote the present study "Feminine names in current Romanian hodonymy" to Barbara Czopek-Kopciuch.

* This study is a part of the research project International Scientific Cooperation for Exploring the Toponymic Systems in the Carpathian Basin, ID: NKFI 128270 (English: NRDI 128270), supported by the National Research, Development and Innovation Fund (Hungary).

${ }^{1}$ We cannot omit the good collaboration within four editions of the International Conference on Onomastics "Name and Naming" (ICONN 2-5: https://onomasticafelecan.ro), held in the years 2013-2019, when Barbara Czopek-Kopciuch was a member of the Scientific Committee. 
This topic has not been addressed to date in Romanian onomastics. Even in the international specialized bibliography, only a few studies are dedicated to female hodonymy, as the traditional nomenclature had an almost exclusively male component. Recent publications include "Female Street Namesakes in Selected Polish Cities' (Walkowiak, 2018, pp. 331-350), "Commemorative Urban Practices and Gender Equality: The Case of Santiago de Compostela's Urban Anthroponymy" (Novas Ferradás, 2018, pp. 109-129), "Gender-Biased Street Naming in Urban Sub-Saharan Africa: Influential Factors, Features and Future Recommendations" (Zuvalinyenga, Bigon, 2020), Feminine urbanonymy in Polish and Italian linguistic landscapes" (Gałkowski, 2020, pp. 2-53). Regardless of the researched area, Central European, Western European, African, one can notice evident gender inequality regarding the references to women and men in street names. From a sociolinguistic and historical perspective for the Romanian space, one can easily explain the situation. Throughout history, all political, social, military leaders, from Antiquity, the Middle Ages to the modern era, have been men. ${ }^{2}$ A plausible explanation could be deduced from the fact that those who recorded the great deeds and their doers were exclusively men.

From a religious perspective, in Orthodoxy (the religion of the majority in Romania) and Catholicism (with a significant impact in Transylvania), the hierarchy can only be male. Culture and science have traditionally been the prerogative of men, so women were able to access education and manage to assert themselves only in the second half of the nineteenth century (see Smith, 2008). They only gained the right to vote in 1938. All this proves that Romanian society was a masculinized one. The language itself often provides evidence which "proves a certain 'masculinity' at least, both in terms of grammar and the lexicon. Thus, a 'dominant' masculinity can be noticed, for example, in the use of plural forms. If there are four sisters in a family and then a brother is born, it will be said that there are five brothers in the family (although the sisters already form a majority). If there are 29 female students in a class, it is enough for only one male student to come, to then talk about a class with 30 male students" (Munteanu, 2018 , p. 101, orig. Romanian).

In such a context, it should come as no surprise that urban microtoponymy ${ }^{3}$ illustrates, through street names, a "masculine" perspective both in terms of the name givers and the anthroponyms they chose to designate different means of communication. Hodonyms represent reflections of mentalities, of the prevailing

${ }^{2}$ There are notable exceptions too, but they strengthen the rule. For example, Jeanne d'Arc/Joan of Arc, a controversial character in her era (1412-1431), but who was canonized in the $20^{\text {th }}$ century, Saint Teresa of Ávila (1515-1582), canonized in 1622 or the British queens Elizabeth I (1533-1603) and Victoria (1819-1901), Maria Theresa of Austria (1717-1780).

${ }^{3}$ This expression designates boulevards, streets, markets, etc., namely the constituent elements of public space, as opposed to urban macrotoponymy, which refers to the names of localities. 
ideas in society, of a modus vivendi with good and bad parts/with lights and shades. They indicate how communities know how to pay homage to their predecessors and how their name/memory is preserved in the public space.

\section{MATERIAL AND METHODOLOGY}

The act of name-giving depends on a wide range of factors because this responsibility does not belong to a person, but a group of people (mayor, local council, a special committee), often of various ethnicities, with different interests and egos, all related to a historical moment: the sociopolitical regime as a whole. As a result, hodonymy is among the most fluctuating categories of the so-called minor toponymy.

In the present study, we aim to highlight the category of hodonyms based on female anthroponyms. In this sense, considering the Romanian urban configuration, the multitude of cities and, implicitly, the related streets, we decided to restrict the research to a limited number of localities (15) of various sizes, selected from all country areas. We thus focused on the following three categories: large cities, with over 280,000 inhabitants: Bucharest (B), Cluj-Napoca (CJ), Constanța (CT), Craiova (CV), Iași (IS); medium-sized cities, with a population between 120,000-200,000: Bacău (BC), Baia Mare (BM), Oradea (OR), Pitești (PT), Sibiu (SB); small towns with up to 100,000 inhabitants: Călărași (CL), Focșani (FC), Sighetu Marmaţiei (SMM), Suceava (SV), Vaslui (VS). We analyzed the names of the streets for each locality according to the lists available online.

The name of the streets (in which we have also included the alleys, boulevards, paths, riverside streets, squares, sidewalks, roads, etc., where they exist) leads us to the idea that the source of selection is varied. Thus, they range from common words in all spheres of vocabulary (names of plants, animals, objects, weapons, abstract terms, etc.) to proper names such as (inter)national geographical names, many linguistically motivated, names of people, names with historical significance, astronyms or even numbers. The share of these categories of names is unequal; large cities have the most diverse range of names, while small towns barely have a name of anthroponymic origin. This is the reason why we do not specify the number of occurrences, but the percentage of the investigated hodonyms.

Our methodology was the following: we inventoried the share of anthroponyms in the current Romanian hodonymy. Further, from the anthroponyms we selected the ones referring to female characters. We recorded the number of occurrences and the commemorated women's status in the national or international "pantheon". Out of the total number of streets considered in the investigated cities, the share of men's names reaches even up to half of the total number of names: $50.89 \%$ in Suceava, 36.49\% in Craiova, $28.62 \%$ in Vaslui, $22.52 \%$ in Bucharest, Area I; in the case of women, the numbers remain at a percentage 
below 3\%: 2.64\% in Suceava, 2.38\% in Bucharest, Area I, 2.23\% in Craiova, $1.83 \%$ in Constanța, $1.64 \%$ in Vaslui. At the same time, considering the lack of national hodonymic regulations, we also discussed the spelling of street names.

\section{DISCUSSION: CLASSIFICATION AND DESCRIPTION}

3.1. Regarding the corpus, we identified several categories, which we reproduce according to occurrences, without always specifying street, a defining element for any anthroponym that has been included in the category of hodonyms.

3.1.1. Historical characters, members of noble families (princely, boyar, royal families): Ancuța Băneasa, (Mrs.) Chiajna, Clucereasa Elena, Despina/Mrs. Despina, Mrs. Elena, Mrs. Ghica, Mrs. Maria Voichița, Mrs. Oltea/Oltea Lady, Mrs. Stanca, Doamnei, Domnița Anastasia, Domnița Florica, Domnița Ruxandra, Elena Cuza/Elena Doamna/Elena Cuza Doamna, Margareta, Maria Calimachi, Maria Clucereasa, Maria Teresa, Regina Elisabeta, Regina Maria, Rhea Silvia. The highest visibility of women în Romanian hodonymy can be linked with historical characters, members of the ruling families from Romanian lands or the royal family. However, according to the local laws, they never exercised leadership functions. They were noticed only as wives, daughters or mothers and from these positions, they could influence politics, culture, arts, or science. The situation is comparable to that in other cities around the world. In "Mapping the Sexism of City Street Names", Linda Poon (2015) found that "only 2.6 per cent of the city's streets were named after prominent female figures", and "many of the 166 women honoured in Paris were wives and daughters of famous men". "This massive gap of recognition of men and women on street signs exists, ironically, at the same time that Paris is becoming known for its progressive street and transportation policies" (Rose-Redwood, Alderman, Azaryahu, 2018, p. 13). The masculinism of hodonyms can be found in any country (see Schwab, 2020).

The oldest and the most substantial presence in Romanian hodonymy belongs to the wives of the kings of the Hohenzollern-Sigmaringen family, during whose reign independence was obtained, the Great Union took place, and the country developed from all points of view. The name of Queen Elizabeth (1843-1916) dominated interwar hodonymy, and her pen name, Carmen Sylva, even designated a town on the Black Sea: Eforie Sud. ${ }^{4}$ Romanian Queen Marie (1875-1938) distinguished herself through her involvement in helping the wounded in the First World War, for the diplomatic qualities that helped the international recognition of the reunited Romanian state, and for supporting artists and writers. The popularity she enjoyed during her life contributed to her presence in the street nomenclature

4 "In numerous situations, the new localities were designated by means of commemorative, celebratory names, inspired by the history" (Felecan, 2019, p. 59). 
not only in the interwar period but also after 1989: Regina Maria Municipal Park (Baia Mare), Regina Maria Blvd. (Bucharest), Regina Maria Street (ClujNapoca, Alba Iulia, Râmnicu Vâlcea, Dej, Iași, Sibiu — between 1919-1947), Regina Maria Square (Timișoara). The only queen whose name did not appear în Romanian hodonymy was Elena (1896-1982). Her lack of popularity is related to her tragic destiny, marked by her divorce from Charles II, the drastic restriction of her rights (personal and public) and the establishment of communism. She spent most of her life in exile in Florence, and as a sign of recognition, the Italian City Council decided to name a street after her (Mazilu, 2021).

The only foreign historical figure is Maria Teresa (B), the leader of the Habsburg Empire between 1740-1780, and a supporter of the Romanians from Transylvania. In addition to her duties as Archduchess of Austria, Queen of Bohemia, Queen of Hungary, she was also the Grand Princess of Transylvania. She remained in the collective memory for her work here. A prime example is the Măriuții Road, ${ }^{5}$ which crosses Gutâi Mountain, the former being a route by which the salt extracted in the Historical Maramureș was transported to Baia Mare and further to the Austro-Hungarian Empire.

3.1.2. Common, ambiguous names, which, without additional details, can spark interpretive confusion: Amalia, Anastasia, Bogdănița, Cornelia, Cosmina, Diana / Diana, Elena, Elena Pleșoianu, Elisabeta, Eliza Moroiu, Filofteia Popescu, Firuța, Flavia, Florica, Irina Stănescu, Larisa, Maria Lăzărescu, Maria Moscu Hagi, Măriuca, Marta, Mixandrei, Popova, Rodica, Silvia, Suzana, Zamfira. Whether they are simple first names or appear with the last name, they are opaque to most people. Some may be only of local importance, which is why they cannot be found in encyclopedias or, due to anthroponymic homonymy, ${ }^{6}$ the reference considered by local authorities (who are entitled, according to the laws in force, to decide the street nomenclature) remains uncertain. The ambiguity is proved in the case of Popova Street (CR), which can refer variously to a Russian chemist (end of the $19^{\text {th }}$ century), a Russian avant-garde artist (beginning of the $20^{\text {th }}$ century), or a Moldavian sportswoman, Olympic rowing champion in 1980. Only the nominating local authorities can decipher the "mystery".

The ambiguity of these street names makes them deeply gendered. Because of the absence of their memory and heritage within traditional place-based names, they do not have the power to impose themselves in the collective memory, to

${ }^{5}$ The diminutive form of the name (Măriuța $<$ Maria + dim. suffix - uța) in Romanian attests to the popularity enjoyed by the Viennese empress among the Transylvanian Romanians.

${ }^{6}$ An approach to the issue related to anthroponymic homonymy can be found at Felecan D.: An unconventional anthroponym is the named subject's signum singulare and may convey:

a) a practical necessity: to avoid anthroponymic homonymy (several bearers for a particular name); or

b) the intention to qualify a human type [...]" (2014, p. 21). 
convey an emotion. They are not "expressions of power and politics" (Drozdzewski, 2018 , p. 114), culture or science. Their names on street signs are not much more than female proper nouns.

3.1.3. Heroines of wars or revolutions (1848, 1989): Ana Ipătescu, Ancuța Ilie, Serg. Maj., Ioana Ursulescu, Capt., Diana Alexandra Donea, Ecaterina Teodoroiu, Ecaterina Varga, Luiza Mioara Mirea, Mihaiela Ruxandra Marcu, Palaghia Roșu, Tina Radu, soldier, Zinca Golescu. The significant number of occurrences in this category shows that Romanians' attention is attracted, especially, to heroic deeds, to the people who sacrificed their lives for the freedom, independence and union of Romanians. Most occurrences in the hodonymy of the researched cities appear in the case of Ana Ipătescu (B, BC, BM, CJ, CR, CT, FC, OR, PT, SB, SMM, SV, VS), Ecaterina Teodoroiu (B, BC, BM, CJ, CL, CR, CT, $\mathrm{OR}, \mathrm{SB}, \mathrm{SV}, \mathrm{VS})$ and Ecaterina Varga (B, BC, CJ, CT, FC, OR, SB). If the second is a heroine of the First World War, the first and the third link their names to the Revolution of 1848. Regarding the last name, it should be noted that it is an ethnic Hungarian (Varga Katalin) who fought for the rights of Romanians in Transylvania, against the abuses of the imperial authorities. As proof of the ethnic sensitivities reflected in the street nomenclature, her name does not appear in localities with a Hungarian ethnic majority, numerous in certain parts of Transylvania, but, in the Romanianized form, in those that have a Romanian administration. This fact demonstrates the different perceptions of the same historical figure (traitor/heroine), depending on the ethnicity of local political decision-makers. "The names might be considered offensive to a certain political ideology (Christian democracy, socialism, liberalism, nationalism, among others" (Felecan, 2015, p. 233). At the same time, the name Varga Katalin appears in the street nomenclature of several cities in Hungary (including Budapest and Győr), which demonstrates the different perception of the Transylvanian woman in the memory of the Hungarians from the neighbouring country. Detachment, moving away from a complex historical event/character, allows an objective perception of it, sine ira et studio.

Of particular interest are the lack of female names related to the Unification of Transylvania with the Kingdom of Romania (1918), the greatest accomplishment of the Romanian political elite. "As one can notice, the list of those who have prepared and established the Unification does not include any women; thus, there are no streets in present-day public space related to the Great Union and bearing women's names. Although this situation could be construed as deeply gendered, it can be accounted for, on the one hand, by the position of women in Romanian society in the past century and, on the other, by their engagement in political life and the movement of national liberation" (Felecan, 2020, p. 504).

Another explanation is related to the participation of only men in that event, which involved a high degree of danger in the context of the end of the First World War, but also the collapse of the Austro-Hungarian Empire. 
The names of the women killed during the events of December 1989 are also missing from contemporary street nomenclature. Bucharest currently pays homage to the names of those who were shot in the anti-communist revolution, a list that includes five women.

3.1.4. Religious characters, all related to Christianity: Maica Domnului [Mother of Lord], Fecioara [Virgin], Maica Alexandra [Mother Alexandra], Maica Teofana [Mother Teofana, Sf. Constantin şi Elena [St. Constantine and Helen], ${ }^{7}$ Sfânta Agnes [St. Agnes], Sfânta Ana [St. Anne], Sfânta Ecaterina [St. Catherine], Sfânta Maria [St. Mary], Sfânta Vineri [Good Friday]. "Romania is one of the most religious countries in the world. According to the Global Index of Religion and Atheism - 2012, compiled by Gallup International, Romania is the seventh state in the world and the first in the European Union concerning religiousness, as 89 per cent of the population claims to be religious" (Felecan $2020 \mathrm{a}, \mathrm{p} .1$ ). However, it seems that the association of religion with femininity is not commonly accepted, as evidenced by the relatively timid presence of women's names in current Romanian hodonymy, compared to those of Orthodox hierarchy, Greek Catholics, Roman Catholics, Protestants, Jews, who enjoy much greater representativeness (see Felecan, 2021a). Indeed, Romanians like to call their country "the garden of the Mother of Lord", a linguistic reality confirmed by Pope John Paul II and Pope Francis during their visits to Romania in 1999 and 2019, respectively. ${ }^{8}$ Yet, the name of Virgin Mary is recorded only once in the capital city. A tacit, traditional taboo can explain the avoidance of the names such as Jesus, Christ or the Virgin Mary in profane contexts; however, some

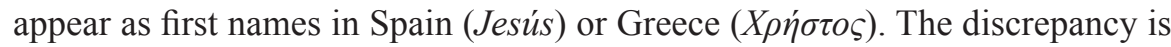
considerable when compared to other Catholic countries (Poland, Spain): "the overall number of streets devoted to saints is the highest in Częstochowa, the site of the most famous Catholic shrine in Poland. Relatively many of the commemorated saints are women (36 per cent)" (Walkowiak, 2018, p. 343). Among the examples identified, most of the holy names, only two refer to nuns. As we have remarked on another occasion, "The preservation in the collective memory the street nomenclature - of the names of some church faces is equivalent, from a secular perspective to the eternal remembrance existing in a religious context. Benefiting from the help of local authorities, street names inspired by the lives and work of priests, monks and high ecclesiastical figures can be compared to civic canonization" (Felecan, 2021a).

\footnotetext{
${ }^{7}$ If they are honoured together in the Christian calendar, this is also reflected in the street nomenclature. Thus, the name of the Roman emperor Constantine, who legalized the Christian religion in 313 by the "Edict of Milan" (lat. Edictum Mediolanense), is always associated with his mother, Elena.

${ }^{8} \mathrm{https}$ ://www.mediafax.ro/social/the-most-beautiful-statement-of-pope-franciscan-romania-isthe-garden-of-mother-of-lord-a-mother-who-cultivates-sons-dreams-18152819.
} 
3.1.5. Female writers: Elena Farago, Elena Văcărescu, Eliza Opran, Magda Isanos, Maria Cunțan, Marta Bibescu, Otilia Cazimir, Veronica Micle. Less publicized than male writers, women have been in the literary landscape since the 19th century. All those present in the names of streets were active in the past. There is a pronounced restraint in choosing the names of living people in Romanian public space, even if they are internationally recognized. A case in point is that of Herta Müller, recipient of the 2009 Nobel Prize in Literature. Born and educated in Romania, a reality which had served as a source of inspiration for the topics of her books, the German novelist is not found in the street nomenclature of her country of origin. In 2012, the Local Council of Timișoara, the city where she attended high school and university, proposed that a street bear her name as a sign of recognition. Still, the proposal was rejected, under the pretext that "it is not appropriate to name some streets after the names of living people" (Both, 2021). It seems that Herta Müller's world fame did not matter; according to the principle that "no one is a prophet in his country", they exploited the power of a rule with no legal backup, a rule which was not respected in other localities. In Germany, however, her name already appears in the street nomenclature: Herta Müller Straße in Gundelsheim, Baden-Württemberg, ${ }^{9}$ which confirms a difference in the treatment of contemporary personalities, existing in the country of residence/country of origin in the case of the Nobel Prize winner.

One can notice a particular situation in the case of the poet Veronica Micle, whose name can be found in the street nomenclature in Iași, where she spent her life, but also in Bacău, Bucharest, Constanța, Suceava, Vaslui; in Iasi and Bucharest her name has been used even more times to name streets, alleys, entrances, dead ends. We are inclined to believe that her name in six cities is due not so much to her publishing activity but especially to her friendship with the Romanian national poet, Mihai Eminescu, and to the early, tragic demise of both in the same year (1889).

3.1.6. Actresses who performed both in Romania and abroad: Agatha Bârsescu, Aglae Pruteanu, Aristița Romanescu, Aura Buzescu, Elena Ghica, Eufrosina Popescu, Leopoldina Bălănuță. As in the case of women writers, the actresses whose names were immortalized on street signs lived a long time ago, the last having died at the end of the last century (Leopoldina Bălănuță). This indicates a certain reluctance in choosing contemporary names for street names. Hodonyms in the Romanian space are linked to what happens in other countries: "female civil figures are more related to the art world (filmmaker, dancer, actress, painter, drawer and musician), as well as teachers, academics, activists, writers, politicians, scientists, unionists and philosophers" (Novas Ferradás, 2018, p. 122).

Several women after whom streets in Romania are named were active in many fields, being actresses, singers, writers or painters at the same time: Anda

\footnotetext{
${ }^{9}$ https://www.neue-strassen.de/baden-wuerttemberg/gundelsheim/herta-müller-straße
} 
Călugăreanu, Cella Delavrancea, Elena Bibescu, Margareta Sterian. They deserve their place in the Romanian "Pantheon" and the perennial homage through everything they have done. Strange, however, is the absence of their foreign counterparts, much better known worldwide but ignored by the local authorities responsible for the by-elections held in public. Instead, foreign names can be found in the names of some institutions (Maria Sklodowska Curie Children's Emergency Clinical Hospital Bucharest), but not in the street nomenclature. One of the reasons is probably the wish to avoid the orthoepic and spelling difficulties of some foreign anthroponyms, especially from non-Romance languages, given that many websites fluctuate in offering the full name of the Marie (S.) Curie, including Google Maps:

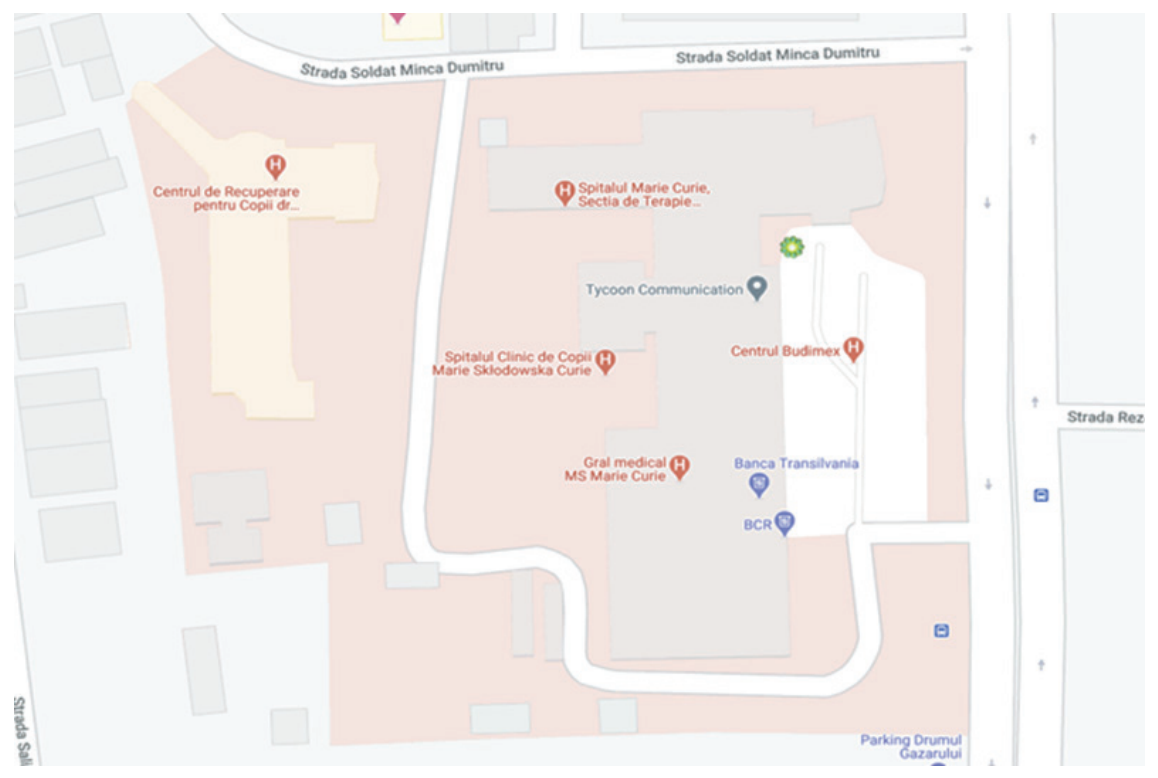

The present situation reveals a certain dose of nationalism, on the one hand, and misogyny, on the other, since men are not subjected to "the same treatment". ${ }^{10}$ If one examines the European space in comparison with one culturally close to Romania, in this case the French, he or she can find there streets named after some famous Romanian female figures: Rue Anna de Noailles (40 occurrences, including Paris), Rue Anna Pauker (a Romanian communist leader!), Cour Marthe Bibesco (Savigny-le-Temple) (see Rateau, 2011, pp. 457, 460) and, starting with 2019,

${ }^{10}$ The reluctance of local authorities is not found in the case of masculine names, taken from Germanic or Slavic languages, which also pose spelling and orthoepic problems to Romanian speakers: Ludwig van Beethoven Street (B, CJ, CV, etc.), Wolfgang Goethe Street (CJ, SB etc.). 
The Promenade Marie de Roumanie, which is named after Romanian Queen Marie, within walking distance of the Eiffel Tour (Paris) (Fontaine, p. 2019).

3.1.7. Characters from Romanian or universal mythology (Greco-Roman). It is the only category in which Romanian names (Dochia, Ileana Cosânzeana, Vrâncioaia / Vrâncioaiei) are in relative balance with the foreign ones (Minerva / Minerva, Venera / Venus). However, their foreign dimension is relative since the Romanian language is the heir of the Latin language, and the Romanians are the Romans' successors in the Carpathian-Danubian-Pontic space. Implicitly, Greco-Roman mythology and the Roman Empire's cultural inheritance were appropriated by compatriots as common heritage to the entire Romanic space, from the Iberian Peninsula to Romania.

3.1.8. The remaining names will be treated together in one category, as they have no more than 3 occurrences. The number of women inventors, pioneers in specific fields of science, doctors, researchers is low in the 15 cities researched: Ana Aslan, Elena Caragiani, Elisa Leonida Zamfirescu. The same is true of journalists, activists for women's rights: Ecaterina Raicoviceanu, Maria Rosetti. Their number is small because, compared to other countries, the feminist movement has never been widespread in Romania.

Several hodonyms are toponymically motivated, as they evoke former owners of the lands where the streets are currently located: Filofteia Gheorghiu, Maria Ghiculeasa. Representatives of bygone eras, long before communism, characters of this type demonstrate the connection of hodonymy with the historical, national context, with specific social and cultural values, in general. "The naming of places is a key component in the relationship between place and the politics of identity in contemporary societies. In this sense, naming is a form of norming. Names are part of both a symbolic and a material order that provides normality and legitimacy to those who dominate the politics of (place) representation" (Berg \& Kearns, 1996, p. 99). The choice of street names after the names of former landowners, banned during the communist dictatorship, is a reparative act, a reply to the purge action, "from the inventory of Romanian placenames [of] the items that were reminiscent of the royal family and key political figures of the former "bourgeois-landowning" regime" (Felecan, 2017, p. 79).

A linguistic motivation can also be perceived in other situations, even if the anthroponymic reference is not on the first position: Hanul Ancuței [Ancuței's Inn] (B), Madona Dudu ${ }^{11}$ (CR), Stadionul Național Lia Manoliu [Lia Manoliu National Stadium] (B), Teiul Doamnei [Lady's Linden Tree] (B). The last two

${ }^{11}$ Madonna Dudu is one of the largest churches in Craiova, dedicated to the Assumption, built between 1750-1756. According to legend, the church was named after the Icon of the Mother of Lord, a miracle, which was found in a mulberry tree (Apostolache, 2009). 
examples must be correlated with the neighbourhoods, as they are related to the sports arena and the park, which bears the same name, ${ }^{12}$ respectively to Str. Lacul Tei [Lake Linden Street].

The only artery in Bucharest that bears the name of a living personality is $\mathrm{Ga}$ briela Szabo Street. The name of the streets in the Capital is handled by a special commission, which includes historians, museographers and specialists in urban nomenclature. Although the regulation that entered into force in 2007 states that "people's names will be assigned at least three years after their death" (see Chilianu, 2017), it seems that exceptions can be made. Gabriela Szabo was an Olympic champion who remained close to the world of sport following her retirement but also entered politics, becoming a minister.

A different motivation of the linguistic sign can be perceived in the naming of some streets after local personalities, who were born or lived a good part of their life in the respective city. For example, in Suceava, there is an Ileana Bardă street, after a painter from Bukovina, and in Bucharest, there is Iza Emilia Street, which evokes a young woman injured in 1945, at an anti-communist demonstration in the capital.

An "anachronic oddity" in the Romanian hodonymic landscape is the maintenance of the names of some communist militants: one Romanian, Elena Pavel (SV), another of Polish origin, Roza Luxemburg ${ }^{13}$ (B), who was active in Germany. They

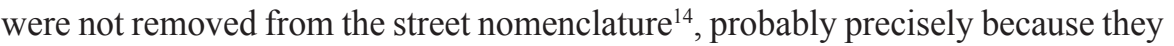
were women, but, according to power relations, dominance, contention, each new political power assumes the appropriation of public space. "Street name changes to accord with, and give material expression to, a regime's sanctioned version of history and ideology, weaving narratives of historical longevity into the streetscapes" (Drozdzewski, 2018, p. 114). It is interesting that checking on the internet, we found only a single occurrence of Róża Luksemburg street in Poland (in the town of Gliwice, Silesia). We could also track this hodonym in Skopje (North Macedonia), Tiraspol (Transnistria, Republic of Moldova), Atbasar (Kazakhstan). Her presence in the Eastern European space is not surprising, but Rosa-LuxemburgStraße in Berlin should be interpreted as a sign of "political correctness" rather than a homage to a political theorist, partisan of Marxism.

We cannot omit the names of some women who fought against communism during the years of the dictatorship established by the Soviet army after the Second

${ }^{12}$ It evokes Lia Manoliu, an athlete with an Olympic longevity record, mentioned in Guinness World Records: she participated in 6 consecutive editions of the Olympic Games (from Helsinki 1952 to Munich 1972), winning several medals.

${ }_{13}$ We respected the Romanian street spelling.

14 "While totalitarian authorities were disturbed by names that were against the regime, current authorities do not see the change of several settlement names as a priority" (Felecan, 2017, p. 84). 
World War: Elisabeta Rizea (IS, B — a park). Their heroic example, morally upright stand, courage, dignity, honoured the Romanian people, in particular, and the human condition, in general.

From what we have outlined so far in terms of feminine names and hodonyms, we can draw two concluding remarks, both essential for our research. Taking as a benchmark the localities, one has to admit that there is a big difference between the number of records: Bucharest (83), Constanța (20), Craiova (16), Iaşi, Suceava (9), Piteşti (8), Bacău, Cluj-Napoca (6), Focşani, Vaslui (5), Sibiu (4), Baia Mare, Oradea (3), Călărași, Sighetu Marmației (1). By provinces, there is a higher share in the southern part of the country: 128 names, then in Moldova 34 and, lastly, Transylvania, with 17 names.

These findings, rendered as a percentage, lead to the following situation, made for several important cities taken as references: in Bucharest, Area 1, with a total of 1008 streets, the names of those from anthroponyms amount to 251 , representing $24.90 \%$, almost a quarter of the total number. Of these, 227 are men's names, with a share of $22.52 \%$, and only 24 are women's names, which is $2.38 \%$; in Constanța, with 1146 streets, only 21 are female names, which is $1.83 \%$; in Craiova, with 718 streets, $278(38.72 \%)$ come from anthroponyms, of which there are 262, or $36.49 \%$, male names, and 16 female ones, representing $2.23 \%$; in Suceava, with 340 streets, $182(53.53 \%)$ come from anthroponyms, of which 173 are male names and represent $50.89 \%$, and 9 come from female names, representing $2.64 \%$; in Vaslui, with 304 streets, 92 anthroponyms, representing 30.26\%, of which 87 $(28.62 \%)$ are men's names, and $5(1.64 \%)$ come from women's names.

\section{INCONSISTENCIES IN THE SPELLING OF STREET NAMES}

Investigating 15 cities across Romania, we found a lack of orthographic consistency, which can generate some confusion in the perception of residents, passers-by or tourists. Those inconsistencies could be grouped as follows:

4.1. The order of the two elements of the anthroponymic formula, name and surname, right inside the same city: Ana Aslan/Aslan Ana, Ana Ipătescu/Ipătescu Ana, Marta Bibescu/Bibescu Marta, Maria Rosetti/Rosetti Maria. The situation is repeated when the first name is accompanied by a determiner: Oltea Doamnal Doamna Oltea, Maria Clucereasa/Clucereasa Maria etc. This inconsistency often creates situations that are difficult to decipher, especially when both elements have identical values (first name and last name): Tina Radu/Radu Tina, Iza Emilia/Emilia Iza, Elena Pavel/Pavel Elena. For those less acquainted with the norms, the street anthroponymic formula remains ambiguous, as the academic norms of the Romanian language prescribe the placement of the first name (pref. pre- means "before", as in Latin) before the family name, with a few exceptions: the school system, the legal system, and often the medical one. 
4.2. Placing the military rank before the name, but without other specifications: Capt. Ioana Ursulescu, Serg. Maj. Ancuța Ilie, Soldier Tina Radu. Without any additional notes, that phrase does not justify its status, given the multitude of these ranks in the army. Given that most of these young women gained their place in the street nomenclature through their heroic death in December 1989, when they took to the streets to demand their freedom, we consider that the mention of military rank should be placed after the name. An additional explanatory note, such as "Hero of the Revolution of December 1989", following the name, would clarify the situation and contribute to passers-by's education by continuously recalling the event.

4.3. Incorrect rendering of names in the street nomenclatures available online: Aristia Romanescu instead of Aristița Romanescu, Filfteia Popescu instead of Filofteia Popescu, Soldier Floarea Gheorghe instead of Flore Gheorghe, Soldier Floarea Ionescu instead of Flore Ionescu, Teodorovici Doina and Aldea instead of Ion and Doina Teodorovici Aldea. Such examples reveal some officials and computer scientists' total disinterest and negligence in recording the street names on specialized websites.

4.4. The use of first names with a high degree of use, without a mention of the respective personality, produces difficulties in deciphering, and the names remain opaque for everyone: Amalia (CT), Cornelia (B), Cosmina (B), Flavia (B, CT), Florica (B), Larisa (B), Măriuca (B), Rodica (B, CT), Suzana (B). Simultaneously, these street names validate the lack of professionalism of the specialized commissions, which have as attributions the choice of the urban nomenclature from certain localities.

4.5. Some first names appear in the genitive case: Dianei, Doamnei, Minervei, Venerei, Vrâncioaiei, etc. In such situations, the name does not have any of the genitive values but is a simple apposition, which lacks another word in the nominative or even a sentence, whose attribute was: Diana Street $<$ Diana's Street [where there is a temple of/ the church of], Lady's Street, etc. These examples show "the complexity of nominal coding in street nomenclature and the possibilities of misinterpreting a single reference. In order to avoid possible confusions, it would be necessary to standardize, impose and respect some norms" (Felecan, 2021a) for the whole country.

\section{CONCLUSION}

Because "the study of the gender politics of street naming is still a woefully neglected theme in urban studies and critical toponymic scholarship" (RoseRedwood, Alderman \& Azaryahu, 2018, p. 13), the present paper offers a unique image of the Romanian public space. This reality, mirrored by hodonyms, is an androcentric one, as throughout history public life used to belong almost 
exclusively to men. Women only came out of the private and domestic spheres in the nineteenth century, and this justifies, in a way, the much smaller number of hodonyms that are claimed by female names. As Rose-Redwood, Alderman and Azaryahu note, "while urban toponymic patterns are highly racialized, they are also deeply gendered" (2018, p. 13), but with a significant discrepancy between the two sexes. The masculinity of the contemporary hodonymic landscape alludes to a society firmly anchored in patriarchal domination.

This study is an attempt to cover the hodonyms of all the domains in which representatives of women excelled. In the current Romanian street nomenclature, one can find historical characters, members of noble families (princely, boyar, royal families); common, ambiguous names; heroines of wars or revolutions (1848, 1989); religious characters, all related to Christianity; female writers; actresses, singers; characters from Romanian or universal mythology (Greco-Roman); women inventors, pioneers in specific fields of science, doctors, researchers; journalists, activists for women's rights; former owners of the lands where the streets are currently located; women from the world of sports; (anti-) communist militants. However, some notable absences can be noted, if one takes a closer look at a top of Romanians with the most significant contribution at the international level (25 de românce care au schimbat lumea — Gândul (gandul.ro) [25 Romanian women who have changed the world]): Elena Negruzzi (the first female lawyer in Romania), Marina Stirbey (one of the best trained European pilots), Iulia Hasdeu (daughter of a scientist, brilliant young woman, the first Romanian woman to study at Sorbonne, Paris), Elvira Popescu (Romanian-French stage and film actress and theatre director), Alice Voinescu (the first Romanian woman to become a Doctor of Philosophy at Sorbonne, imprisoned by communists without being tried or convicted), Sarmiza Bilcescu (the first woman in the world to obtain a PhD in Law according to the World Record Academy), ${ }^{15}$ Aurora Gruescu (the world's first woman forestry engineer), Sofia Ionescu (considered to be the first female neurosurgeon in the world to perform brain surgery), Nadia Comăneci (the first gymnast to score a perfect 10 at the Olympics), ${ }^{16}$ Irina Burnaia (the first female pilot to fly over the Carpathian Mountains), Florica Bagdasar (a Romanian neuropsychiatrist, who was the first woman minister in Romania). All these examples demonstrate that the number of famous women in Romania is sufficient to name streets.

\footnotetext{
${ }^{15} \mathrm{https} / /$ www.worldrecordacademy.org/amazing/worlds-first-woman-with-a-doctorate-in-lawsarmiza-bilcescu-alimanisteanu-219231.

${ }^{16}$ Even though it is not honoured in the hodonymy of her native country, in Spain, there is a city (San Andreas del Rabanedo) where the authorities have decided that an artery should be named after the gymnast who obtained the perfect 10, as a sign of appreciation for "Nadia's unparalleled performance at the Olympics since 1976, from Montreal” (Ionașcu, 2012).
} 
Urban development involves the emergence of new traffic arteries, and the names of famous women can be a source of inspiration in choosing the hodonyms. "The naming of streets is a political act, but it is much more than this as well [...]. A seemingly mundane aspect of urban administration, street naming systems also make up very foundations of urban spatial imaginaries. Naming streets, therefore, plays an important role in the making of 'urban worlds,' and the act of street naming is one of the primary means of historicizing space and spatializing history" (Rose-Redwood, Alderman \& Azaryahu, 2018, p. 309). The recognition of women's role in society and their commemoration through hodonyms play the role of a restorative act, a heteroglossia of many voices juxtaposed in a common space. The polyvocality of the nominees must be correlated with the complexity of contemporary reality, in which the power asymmetries are visibly diminishing, but without demolishing myths and personalities for the sake of change. An injustice of history cannot be corrected by a random decision, taken under the pressure of groups, events, or fashion. The fight against discrimination must not be turned into a war against names (see Felecan, 2021, pp. 45-48).

\section{REFERENCES}

Apostolache, I. (2009, March 17). Legenda Bisericii "Madona Dudu" [The Legend of the Church "Madonna Dudu"]. Ziarul Lumina. https://ziarullumina.ro/actualitate-religioasa/documentar/ legenda-bisericii-madona-dudu-46959.html

Both, Ș. (2012, May 4). EXCLUSIV Strada Herta Müller din Timişoara nu a fost acceptată pe motiv că scriitoarea este în viață [EXCLUSIVE Herta Müller Street in Timişoara Was Not Accepted on the Grounds that the Writer Is Alive]. Adevărul. https://adevarul.ro/locale/timisoara/ exclusiv-strada-herta-muller-timisoara-nu-fost-acceptata-motiv-scriitoarea-viata-1_50aee15e7c 42d5a663a16f8e/index.html

Berg, L.D., \& Kearns, R.A. (1996). Naming as norming: "Race", gender, and the identity politics of naming places in Aotearoa/New Zealand. Environment and Planning D: Society and Space, 14, 99-122.

Chilianu, D. (2017, December 30). Singura stradă din București cu numele unei personalități care trăiește! [The Only Street in Bucharest with the Name of a Living Personality!]. Libertatea. https://www.libertatea.ro/stiri/strada-care-poarta-numele-atletei-gabriela-szabo-2092106

Czopek-Kopciuch, B. (2013). Names of companies in Poland. In O. Felecan, \& A. Bugheșiu (Eds.), Onomastics in Contemporary Public Space (pp. 120-130). Newcastle upon Tyne: Cambridge Scholars Publishing.

Czopek-Kopciuch, B. (2021). Multiculturalism in Polish toponymy. In O. Felecan, \& A. Bugheșiu (Eds.), Names and Naming: Multicultural Aspects (pp. 331-343). New York: Palgrave Macmillan.

Drozdzewski, D. (2018). Locating the geopolitics of memory in the Polish streetscape. In R. RoseRedwood, D. Alderman, \& M. Azaryahu (Eds.), The Political Life of Urban Streetscapes. Naming, Politics, and Place (pp. 114-131). Abingdon: Routledge.

Felecan, D. (2014). Prolegomena to a different kind of naming: name-giving between the conventional and unconventional. In O. Felecan, \& D. Felecan (Eds.), Unconventional Anthroponyms: Formation Patterns and Discursive Function. Newcastle upon Tyne: Cambridge Scholars Publishing. 
Felecan, O. (2015). Borders and ethnic identities reflected in street names from Transylvanian Localities. Transylvanian Review, XXIV, Supplement no. 1: Regionalization in Globalisation, 229-244.

Felecan, O. (2017). Oikonymic transformations in Romania in the second half of the twentieth century. Names, 65(2), 78-87. https://doi.org/10.1080/00277738.2016.1262132

Felecan, O. (2019). Oikonymic transformations in Romania in the first half of twentieth century. Dacoromania, XXIV/1, 57-65.

Felecan, O. (2020a). The Romanian Orthodox Church and higher education: between academic freedom and constraint. Diacronia, 11(A164), 1-6. https://doi.org/10.17684/i11A164en

Felecan, O. (2020b). Romanian oikonyms and hodonyms mirroring the Great Union of 1918. Mitteilungen der Österreichischen Geographischen Gesellschaft, 162, 495-517. https://doi. org/10.1553/moegg 162 s495

Felecan, O. (2021a). A semiotic perspective on the presence of Clergy in Romanian hodonymy. In M. Kopytowska, A. Gałkowski, \& M. Leone (Eds.), Thought-Sign-Symbol: Cross-cultural Representations of Religion. Frankfurt am Main: Peter Lang (in press).

Felecan, O. (2021b). Onomastic considerations on certain news items in the recent mass media. In A. Choleva-Dimitrova, M. Vlahova-Angelova, \& N. Dancheva (Eds.), Proceedings of the International Onomastic Conference "Anthroponyms and Anthroponymic Researches in the Beginning of the $21^{\text {st }}$ Century” (pp. 42-58). Sofia: Prof. Marin Drinov Publishing House of Bulgarian Academy of Sciences.

Fontaine, N. (2019, October 16). Une partie du quai Branly rebaptisée «promenade Marie de Roumanie» en présence de la princesse Margareta et Stéphane Bern. Histoires Royales. https:// histoiresroyales.fr/inauguration-promenade-marie-de-roumanie-quai-branly-paris/

Gałkowski, A. (2020). Feminine urbanonymy in Polish and Italian linguistic landscapes. Lege Artis. Language Yesterday, Today, Tomorrow, 5(1), 2-53.

Ion aşcu, R. (2012, February 27). Nadia Comăneci dă numele unei străzi dintr-un oraş spaniol [Nadia Comăneci Gives the Name to a Street in a Spanish City]. Libertatea. https://www.libertatea.ro/ sport/nadia-comaneci-da-numele-unei-strazi-dintr-un-oras-spaniol-708521

Mazilu, P. (2021, January 28). O stradă din Florența va purta numele Reginei Elena a României [A Street in Florence Will Be Named After Queen Elena of Romania]. Mediafax. https:// www.mediafax.ro/life-inedit/o-strada-din-florenta-va-purta-numele-reginei-elena-a-romaniei-19886516

Munteanu, C. (2018). Când vorbitorul nu are dreptate. Câteva observaţii referitoare la „,masculinitatea" limbii române [When the speaker is not right. Some remarks regarding the "masculinity" of the Romanian language]. Philologica Jassyensia, XIV, 1(27), 97-106.

Novas Ferradás, M. (2018). Commemorative urban practices and gender equality: The case of Santiago de Compostela's urban anthroponymy. Hábitat y Sociedad, 11, 109-129.

Poon, L. (2015, November 4). Mapping the Sexism of City Street Names. Bloomberg CityLab. https:/www.bloomberg.com/news/articles/2015-11-04/mapping-the-sexism-of-street-namesin-major-cities

Rateau, M. (2011). Noms des voies de communication urbaines françaises ayant un lien avec le pays de Roumanie. Motivations des denominations. In O. Felecan (Ed.), Proceedings of the First International Conference on Onomastics Name and Naming, Multiethnic Connections in Anthroponymy (pp. 453-478). Cluj-Napoca: Editura Mega.

Rose-Redwood, R., Alderman, D., \& Azaryahu, M. (Eds.). (2018). The Political Life of Urban Streetscapes. Naming, Politics, and Place. Abingdon, UK: Routledge.

Schwab, P.N. (2020, March 11). The Feminization of Street Names: Useful Debate or a Political Artifice? IntoTheMinds. https:/www.intotheminds.com/blog/en/feminisation-street-names/ 
Smith, B.G. (Ed.). (2008). The Oxford Encyclopedia of Women in World History. Oxford University Press.

Walkowiak, J.B. (2018). Female street namesakes in selected Polish cities. Mitteilungen der Österreichischen Geographischen Gesellschaft, 160, 331-350. https://doi.org/10.1553/ moegg160s331

Zuvalinyenga, D., \& Bigon, L. (2020). Gender-biased street naming in urban Sub-Saharan Africa: Influential factors, features and future recommendations. Journal of Asian and African Studies, 56(3), 589-609. https://doi.org/10.1177/0021909620934825

https://www.mediafax.ro/social/cea-mai-frumoasa-declaratie-a-papei-francisc-romania-e-gradina-maicii-domnului-o-mama-care-cultiva-visurile-fiilor-18152819 (accessed in March 2021).

Promenade Marie de Roumanie inaugurated in Paris near the Eiffel Tower | Romania Insider (romania-insider.com) (accessed in January 2021).

https://familiaregala.ro/istorie/regina-elisabeta (accessed in March 2021).

https://familiaregala.ro/istorie/regina-maria (accessed in March 2021).

https://familiaregala.ro/istorie/regina-elena (accessed in March 2021).

https://www.neue-strassen.de/baden-wuerttemberg/gundelsheim/herta-müller-straße (accessed in March 2021).

25 de românce care au schimbat lumea — Gândul (gandul.ro) (accessed in March 2021).

\section{SUMMARY}

\section{FEMININE NAMES IN CURRENT ROMANIAN HODONYMY}

This study aims to map the gender politics of contemporary Romanian street naming. Hodonyms mirror mentalities and the ideas prevailing in a society. Urban microtoponimy is an androcentric one, as public life has belonged, throughout history, almost exclusively to men. Women emerged from the private and domestic spheres only in the nineteenth century, and this justifies, in a way, the much smaller number of street names that are claimed by female names. The recognition of women's role in society and their commemoration through hodonyms can function as a reparative act of balancing the power and influence asymmetries. 